\title{
Gram per Square Meter
}

National Cancer Institute

\section{Source}

National Cancer Institute. Gram per Square Meter. NCI Thesaurus. Code C67282.

A metric unit of areal density defined as a spread rate at which one gram of a substance is spread over the area of one square meter. It is equal to approximately 0.0294935 ounce per square yard. Also used as a dose calculation unit to express quantity of an agent in grams per body surface area in square meters. 